\title{
ANALISIS POSTER HASIL KREATIVITAS SISWA KELAS VIII A SMP NEGERI 3 SINGARAJA DARI ASPEK BAHASA DAN ISI
}

\author{
Ni Putu Veni Antari ${ }^{1}$, Made Sri Indriani ${ }^{2}$, Gde Artawan ${ }^{3}$ \\ Program Studi Pendidikan Bahasa Indonesia, Fakultas Bahasa dan Seni, \\ Universitas Pendidikan Ganesha \\ Singaraja \\ veniantari.id31@gmail.com¹, sriindriani6114@gmail.com², \\ gartawan@yahoo.com³@undiksha.ac.id
}

\begin{abstract}
ABSTRAK
Permasalahan yang dibahas dalam penelitian ini yaitu: (1) Bagaimanakah aspek bahasa dalam poster hasil kreativitas siswa kelas VIII A SMP Negeri 3 Singaraja?, (2) Bagaimanakah aspek isi yang terdapat pada poster hasil kreativitas siswa kelas VIII A SMP Negeri 3 Singaraja?. Penelitian ini bertujuan untuk (1) menganalisis bahasa dalam bentuk penggunaan kalimat efektif pada poster hasil kreativitas siswa, (2) menganalisis aspek isi yang terdapat pada poster hasil kreativitas siswa. Subjek dalam penelitian ini adalah poster hasil kreativitas siswa kelas VIII A SMP Negeri 3 Singaraja . Objek dalam penelitian ini adalah bahasa dan isi poster. Metode yang digunakan dalam penelitian ini deskriptif kualitatif. Hasil penelitian menunjukkan bahwa terdapat beberapa ciri-ciri penggunaan kalimat efektif dalam poster hasil kreativitas siswa yaitu: (1) kesepadanan, (2) ketegasan, (3) kehematan. Terdapat aspek isi yang mengacu pada (1) menarik perhatian pembaca, (2) komposisi dasar, (3) kesesuaian gambar dengan pernyataan. Hasil penelitian ini menunjukkan bahwa (1) sebanyak 23 siswa yang berhasil menggunakan kalimat efektif dalam bentuk kesepadanan, 27 siswa yang berhasil menggunakan kalimat efektif dalam bentuk penekanan dan 20 siswa yang berhasil menggunakan kalimat efektif dalam bentuk kehematan. (2) Sebanyak 23 siswa yang berhasil menulis poster dikriteria menarik, 24 siswa berhasil dalam komposisi poster dan 29 siswa yang berhasil mengaitkan gambar dengan pernyataan.
\end{abstract}

Kata Kunci: Poster, bahasa poster

\begin{abstract}
The issues discussed in this research that (1) how do aspect of the language in the poster the results of the creativity of the students of class VIII A SMP Negeri 3 Singaraja?, (2) how do aspects of the content that is contained on the poster the result of the creativity of the students of class VIII A SMP Negeri 3 Singaraja?. This study aims to (1) analyze language in the form of the use of affective sentences on the poster the result of the creativity of the students, (2) analyze aspects of the content that is contained on the poster the result of the creativity of the students. The subjectin this research is a poster of the results of the creativity of the students of class VIII A SMP Negeri 3
\end{abstract}




\author{
e-Journal Jurusan Pendidikan Bahasa dan Sastra Indonesia \\ Volume : 9 Nomor: 2, Agustus 2019 \\ P-ISSN : 2614-4743 (cetak) dan e-ISSN : 2614-2007 (online)
}

\begin{abstract}
Singaraja. Object in this research is the language and the content of the poster. The method used in this descriptive qualitative research. The results of the research show that there are a few traits use effective sentences in the poster the results of students creativity namely (1) equivalence (2) firmness (3) frugality. The are aspects of the content that refers to (1) draw the attention of readers (2) the basic composition (3) The suitability of the image with the statement. The results of this study show that (1) A total of 23 successful students use effective sentence in the form of equivalence, (2) 27 successful students use effective sentence in the form of emphasis and 20 successful students use effective sentence in the form of frugality. (2) 23 students who successfully write the poster on the criteria of interesting, 24 students who succesfully in the composition of the poster and 29 students who successfully associate the image with the statement.
\end{abstract}

Keywords:poster, the use of the language of the poster

\section{PENDAHULUAN}

Keterampilan berbahasa dalam pembelajaran Bahasa Indonesia dapat dibagi menjadi empat aspek yaitu menyimak, berbicara, membaca dan menulis. Keempat aspek tersebut berkaitan dan saling mendukung dalam penyelenggaraaan proses belajar mengajar di kelas. Balitbang, (2002: 65) menyatakan bahwa, keterampilan menyimak digunakan dalam menangkap dan mengumpulkan informasi serta gagasan dari siswa. Keterampilan berbicara digunakan dalam materi, memberi pertanyaan dalam mengelola kelas. Keterampilan membaca digunakan dalam memahami dan menangkap isi pesan secara tertulis sementara keterampilan menulis digunakan menyampaikan pesan secara tertulis, seperti menjelaskan materi secara tertulis ataupun dalam memberikan evaluasi.

Dari keempat aspek tersebut, salah satu bidang aktivitas yang memegang peranan penting dalam pembelajaran bahasa ialah menulis. Slamet dan Khundharu (2009:98) menyatakan bahwa menulis memerlukan keterampilan karena diperlukan latihanlatihan yang berkelanjutan, terus menerus dan sungguh-sungguh. Dalam kegiatan menulislah siswa dapat mengembangkan ide gagasan dan kreativitas yang ada pada dirinya dan dapat ditungkan dalam bentuk tulisan. Selain itu kemampuan menulis dapat mengembangkan kreativitas imajinatifsiswa yang dituangkan dalam berbagai materi yang ada pada pembelajaran Bahasa Indonesia salah satunya adalah pembelajaran menulis poster.

Keterampilan menulis poster adalah salah satu keterampilan yang harus dikuasai siswa SMP/MTs. Keterampilan menulis poster terdapat dalam Kurikulum Tingkat Satuan Pendidikan (KTSP) untuk siswa Sekolah Menengah Pertama (SMP) kelas VIII. Menulis slogan dan poster terdapat dalam Standar Kompetensi (SK): "Mengungkapkan informasi dalam bentuk rangkuman, teks berita, slogan/poster". Termuat dalam Kompetensi Dasar (KD): "Menulis slogan/poster untuk berbagai keperluan dengan pilihan kata dan kalimat yang bervariasi serta persuasif". Poster yang dibuat juga harus menarik perhatian pembaca karena tujuan dibuatnya poster adalah untuk memengaruhi atau mengajak pembaca. Keterampilan menulis siswa seringkali terhambat oleh sulitnya menemukan ide. Kesulitan menemukan ide ini salah satunya dipengaruhi oleh proses pembelajaran 
yang belum berhasil mendorong siswa untuk berpikir kreatif.

Poster merupakan salah satu alat yang memuat pemberitahuan atau informasi tertentu kepada khalayak atau pembaca. Sudjana dan Rivai (2007: 51) mendefinisikan sebagai salah satu visual dari rancangan yang kuat, dengan warna, dan pesan dengan maksud untuk menangkap perhatian orang yang lewat tetapi cukup lama menanam gagasan yang berarti di dalam ingatannya.

Poster dapat dibedakan menjadi beberapa jenis yaitu: poster pendidikan, poster lingkungan, poster kesehatan, poster kegiatan, poster layanan masyarakat dan poster karya seni. Pembelajaran menulis poster merupakan pembelajaran yang dapat melatih daya kreativitas serta imajinatif siswa. Selain itu, poster sangat dibutuhkan dikalangan masyarakat luas.

Menurut Sadiman, dkk. (2007:46), poster berfungsi untuk memengaruhi orang-orang yang membeli produk baru dari suatu perusahaan, untuk mengikuti program Keluarga Berencana atau untuk menyayangi binatang bisa dituangkan lewat poster.Pembelajaran menulis poster tidak hanya berguna bagi dunia pendidikan saja, namun bisa dimaanfaatkan oleh siswa ketika terjun di lingkungan sekitarnya.

Berdasarkan observasi yang penulis lakukan di SMP Negeri 3 Singaraja, semua siswa dari kelas VIII A sampai dengan I memperoleh materi yang sama dalam pembelajaran menulis poster. Dalam proses menulis poster ini, kelas A adalah kelas yang memiliki kemampuan terbaik dan mendapat nilai tertinggi dalam menulis sebuah poster. Hal ini dapat dilihat dari nilai rata-rata siswa kelas $A$ memperoleh nilai antara rentangan 87-75, siswa kelas $B$ memperoleh rentangan 84-65, sedangkan siswa kelas C,D,E,F,G,H dan Imemperoleh nilai antara rentangan 72-60. Selain itu, hasil karya penulisan poster siswa kelas VIII A dikatakan lebih baik dibandingkan dengan kelas-kelas yang lainnya, jika dilihat dari penulisan, kesesuaian tema, pemahaman terhadap penulisan poster, tampilan dan isi dari poster tersebut.

Peneliti memilih menganalisis poster siswa kelas VIII A dari segi bahasa dan isi. Peneliti ingin mengetahui poster yang dibuat oleh siswa kelas VIII A sudah atau belum mengandung aspek bahasa berupa kalimat efektif dan isi yang sesuai dengan aspek-aspek penulisan poster.

Poster biasanya terlihat di tempattempat umum. Seperti di sekolah, jalan raya, pasar, rumah sakit, gerbong kereta api dan sebagainya. Poster dapat dibuat dengan menggunakan kertas, kain, batang kayu, seng, dan sebagainya. Poster memiliki ukuran yang berbeda-beda, bergantung kebutuhan si pembuat. Poster memiliki kegunaan yang begitu tinggi bagi si pengguna poster. Oleh karena itu poster yang ditampilkan haruslah menarik. Oleh karena itu pemilihan kata yang sesuai, memiliki peranan penting yang harus diperhatikan oleh si pembuat poster. Poster yang dibuat hendaknya menggunakan berbagai macam warna dan gambar sesuai dengan konteks yang disampaikan.

Selain menarik perhatian, komposisi poster juga berperan penting dalam isi poster. Hal yang perlu ditonjolkan dalam tampilan poster membedakan antara poin-poin utama yang akan ditampilkan dengan poin-poin tambahan yang difungsikan sebagai pelengkap.Penting untuk memastikan bahwa poin-poin penting yang ditonjolkan menjadi pusat perhatian utama dari pembaca. Poinpoin penting inilah yang nantinya akan selalu diingat oleh pembaca. 


\section{METODE PENELITIAN}

Tercapai tidaknya tujuan penelitian, sangat bergantung pada metode yang digunakannya. Suryana (2010:16) menyatakan bahwa metode penelitian adalah prosedur atau langkah-langkah yang ditempuh dalam penelitian untuk mendapatkan pengetahuan ilmiah atau ilmu.

Rancangan penelitian yang digunakan dalam penelitian ini adalah rancangan deskriftif kualitatif. Pendekatan deskriptif kualitatif digunakan untuk memperoleh gambaran yang jelas, sistematis, objektif, dan cermat mengenai fakta-fakta aktual dan sifat populasi. Pendekatan deskriptif ini dipilih karena rancangan penelitian ini mampu menggambarkan secara keseluruhan deskripsi mengenai penggunaan bahasa dalam kalimat efektif dan isi poster karya siswa kelas VIII A SMP Negeri 3 Singaraja.

Subjek dalam penelitian ini adalah poster hasil kreativitas siswa kelas VIII A SMP Negeri 3 Singaraja sedangkan objek dalam penelitian ini adalah bahasa dan isi. Lokasi dilakukannya penelitian ini yakni di salah satu Sekolah Menengah Pertama (SMP) di Kota Singaraja, yaitu SMP Negeri 3 Singaraja. SMP Negeri 3 Singaraja saat ini dipimpin oleh kepala sekolah yaitu, I Gede Sumatra Jaya, S.Pd. SMP Negeri 3 Singaraja menggunakan dua jenis kurikulum, yaitu Kurikulum Satuan Pendidikan (KTSP) untuk kelas VIII dan XI dan Kurikulum 13 untuk kelas VII.

Metode yang digunakan peneliti ialah metode dokumentasi. Melalui metode pengumpulan data yang tepat dalam suatu penelitian, akan memungkinkan pencapaian pemecahan masalah secara valid dan terpercaya yang akhirnya akan memungkinkan dirumuskannya generalisasi yang objektif (Arikunto, 2006:222). Metode dokumentasi dalam penelitian ini digunakan untuk mencatat data-data yang berkaitan dengan masalah penelitian dalam bukti tertulis yang telah ada. Bukti tertulis tersebut berupa poster karya siswa kelas VIII A SMP Negeri 3 Singaraja yang dikumpulkan melalui metode tes.

Saat melakukan sebuah penelitian, peneliti memerlukan alat-alat untuk mempermudah memperoleh data atau informasi. Alat tersebut adalah instrument penelitian. Instrumen yang digunakan dalam metode dokumentasi adalah pencatatan dokumen, yaitu dalam bentuk kartu data. Teknik analisis data yang digunakan dalam penelitian ini adalah teknik analisis deskriptif kualitatif. Dalam penelitian ini langkah-langkah yang dilakukan yakni pertama, menyiapkan poster yang akan diteliti, yaitu poster yang dibuat oleh siswa kelas VIII A SMP Negeri 3 Singaraja. Kedua, membaca dan mengamati poster yang sudah dikumpulkan secara cermat dan teliti.Ketiga, mengelompokkan poster berdasarkan jenisjenis poster yang dibuat oleh siswa Kelas VIII A SMP Negeri 3 Singaraja. Keempat, Melakukan sampel acak, peneliti memperoleh 31 poster kemudian dikelompokan berdasarkan jenis poster. Peneliti memilih secara acak poster dengan cara membalik foto, poster kemudian dipilih secara acak. Kelima, Menganalisis bahasa dalam kalimat efektif yang mengacu pada penggunaan kalimat efektif dalam bentuk (1) kesepadanan, (2) penekanan, dan (3) kehematan. Keenam, menganalisis kemampuan menulis poster pada aspek isi yang mengacu pada: (1) menarik perhatian pembaca, (2) komposisi dasar dan (3) kesesuaian atau keterkaiatan antara gambar dan tulisan. Ketujuh, menyimpulkan hasil penelitian.

\section{HASIL PENELITIAN DAN PEMBAHASAN Hasil Penelitian}

Hasil penelitian meliputi (1) bahasa poster dalam penggunaan kalimat efektif hasil kreativitas siswa kelas VIII A dan (2) 
e-Journal Jurusan Pendidikan Bahasa dan Sastra Indonesia

Volume : 9 Nomor: 2, Agustus 2019

P-ISSN : 2614-4743 (cetak) dan e-ISSN : 2614-2007 (online)

\begin{tabular}{|c|c|c|c|c|}
\hline \multirow{2}{*}{\multicolumn{2}{|c|}{$\begin{array}{c}\text { Pokok Analisis } \\
\text { Nomor Data }\end{array}$}} & \multicolumn{3}{|c|}{ Deskripsi } \\
\hline & & & S11 & \\
\hline \multirow{2}{*}{\multicolumn{2}{|c|}{ Jenis Poster }} & \multirow{2}{*}{\multicolumn{3}{|c|}{$\begin{array}{c}\text { Pendidikan } \\
\text { "Pendidikan adalah } \\
\text { Hak Semua Orang" }\end{array}$}} \\
\hline & & & & \\
\hline \multirow{4}{*}{$\begin{array}{l}\text { Analisis } \\
\text { dari } \\
\text { Segi } \\
\text { Bahasa } \\
\text { (Keefekt } \\
\text { ifan } \\
\text { Kalimat) }\end{array}$} & & Ya & Tdk. & $\begin{array}{l}\text { Keter- } \\
\text { angan }\end{array}$ \\
\hline & $\begin{array}{l}\text { Kesepa- } \\
\text { danan }\end{array}$ & $\checkmark$ & & \multirow{3}{*}{$\begin{array}{c}\text { Leng- } \\
\text { kap }\end{array}$} \\
\hline & $\begin{array}{l}\text { Peneka- } \\
\text { nan }\end{array}$ & $\checkmark$ & & \\
\hline & $\begin{array}{c}\text { Kehemat } \\
\text { an }\end{array}$ & $\checkmark$ & & \\
\hline
\end{tabular}

aspek isi yang terdapat pada poster hasil kreativitas siswa kelas VIII A SMP Negeri 3 Singaraja. Berikut dipaparkan hasil temuan yang diperoleh dari analisis poster hasil kreativitas siswa kelas VIII A SMP Negeri 3 Singaraja. Data mengenai bahasa dan isi poster hasil kreativitas siswa kelas VIII A SMP Negeri 3 Singaraja diperoleh menggunakan metode dokumentasi. Hasil yang diperoleh dari penggunaan metode dokumentasi yakni sebagai berikut.

Pertama, dari 31 poster yang ditulis siswa yang dianalisis dari segi bahasa dalam penggunaan kalimat efektif diperoleh hasil yang beragam dari setiap siswa. Terdapat $18(58 \%)$ poster siswa yang berhasil membuat kalimat efektif dalam bentuk: kesepadanan, penekanan, dan kehematan. 18 siswa tersebut dituliskan dengan nomor data S07, S21, S27, S23, S15, S19, S28, S10, S17, S01, S13, S03, S20, S04, S24, S10, S22 dan S26. Hasil analisis dari salah satu poster siswa yang lengkap dapat dilihat pada tabel di bawah.

Tabel 01.Bahasa dalam poster hasil kreativitas siswa

Poster dengan tema pendidikan ditulis oleh siswa dengan nomor data S10, dilihat dari penggunaan kalimat dalam bentuk kesepadanan terlihat bahwa adanya unsur subjek dan predikat. "Pendidikan" berfungsi sebagai subjek, sedangkan "hak semua orang" berfungsi sebagai predikat. Kalimat yang terdapat pada poster ini

\begin{tabular}{|c|c|c|c|c|}
\hline \multirow{2}{*}{\multicolumn{2}{|c|}{$\begin{array}{c}\text { Pokok Analisis } \\
\text { Nomor Data }\end{array}$}} & \multicolumn{3}{|c|}{ Deskripsi } \\
\hline & & & S1 & \\
\hline \multirow{2}{*}{\multicolumn{2}{|c|}{ Jenis Poster }} & \multirow{2}{*}{\multicolumn{3}{|c|}{$\begin{array}{c}\text { Pendidikan } \\
\text { "Jagalah Bumi Kita" }\end{array}$}} \\
\hline & & & & \\
\hline \multirow{4}{*}{$\begin{array}{c}\text { Analisis } \\
\text { dari Segi } \\
\text { Bahasa } \\
\text { (Keefekti } \\
\text { fan } \\
\text { Kalimat) }\end{array}$} & & $\mathrm{Ya}$ & Tdk. & $\begin{array}{l}\text { Ketera } \\
\text { ngan }\end{array}$ \\
\hline & $\begin{array}{l}\text { Kesepa- } \\
\text { danan }\end{array}$ & $\checkmark$ & & \multirow{3}{*}{$\begin{array}{l}\text { Leng- } \\
\text { kap }\end{array}$} \\
\hline & $\begin{array}{l}\text { Peneka- } \\
\text { nan }\end{array}$ & $\checkmark$ & & \\
\hline & $\begin{array}{l}\text { Kehe- } \\
\text { matan }\end{array}$ & $\checkmark$ & & \\
\hline
\end{tabular}

sudah termasuk kalimat efektif jika dilihat dari bentuk kesepadanan.Kalimat ini jelas maknanya, hubungan antar unsur menjadi jelas sehingga ada kesatuan bentuk yang membentuk kepaduan makna.Jika dilihat dari penggunaan kalimat efektif dalam bentuk penekanan dalam poster ini sudah menunjukkan kata "pendidikan" merupakan salah satu kata yang mengandung unsur penegasan.Kata "pendidikan" merupakan inti atau pokok utama yang menjadi perbincangan. Melalui poster ini diharapkan setelah khalayak membaca poster tersebut kata "pendidikan" akan selalu diingat dimanapun dan kapan pun. Selain bentuk penekanan kalimat dalam poster harus padat dan berisi.Perlu adanya kalimat dalam bentuk kehematan yang berfungsi untukmenghindari pengulangan subjek dan pemakaian kata hiponim.Pada poster ini kalimat yang digunakan sudah efektif dan tidak berlebihan.

Sebanyak 28 (90,3\%) siswa menciptakan kalimat efektif dalam bentuk penekanan. Hasil analisis dari poster yang dibuat oleh siswa dapat dilihat pada tabel di bawah.

Tabel 02. Penggunaan kalimat bentuk penekanan.

Penggunaan kalimat efektif dalam bentuk penekanan, pada poster hasil kreativitas siswa dengan nomor data $\mathrm{S} 17$ menunjukkan bahawa kata "jagalah" merupakan salah satu bentuk kata yang 
mengandung unsur penegasan. Hal ini ditandai dengan partikel penegas yaitu "lah" pada kata "jagalah" yang berada di awal kalimat.

Sebanyak $22 \quad(70,9 \%)$ siswa menciptakan kalimat efektif dalam bentuk penekanan. Hasil analisis dari poster yang dibuat oleh siswa dapat dilihat pada tabel di bawah.

Tabel 03. Penggunaan kalimat dalam bentuk kehematan

Poster ini merupakan salah satu jenis poster niaga yang biasanya digunakan untuk mempromosikan barang atau pun jasa.Poster cenderung menggunakan katakata singkat dan padat. Pada poster ini masih ada kata yang bersipat mubazir dan harus dihilangkan karena memiliki makna yang sama. Kata "sangat" dan "sekali" memiliki makna sama, sehingga salah satunya harus dihilangkan. Maka kalimat efektifnya menjadi "Cornetto Kemasan Baru dan Rasa yang Sangat Lezat, Ayo Beli Sebelum Kehabisan". Kalimat tersebut lebih cocok dibandingkan dengan kalimat sebelumnya.

Kedua, poster hasil kreativitas siswa yang ditulis oleh kelas VIII A SMP Negeri 3 Singaraja sudah mengandung aspek isi dengan baik. Terdapat 17 (54,8\%) poster siswa yang berhasil membuat aspek isi yang terdapat pada poster yang mereka buat.17 siswa tersebut dituliskan dengan nomor data S07, S14, S23, S15, S28, S17, S01, S05, S03, S18, S20, S06, S16, S24, S09, S26, dan S31. Hasil analisis dari salah satu poster siswa yang lengkap dapat dilihat pada gambar poster di bawah. Aspek isi yang terdapat pada poster siswa meliputi: menarik perhatian, komposisi dasar dan kesesuaian antara gambar dengan pernyataan. Hasil analisis dari salah satu poster siswa yang lengkap dapat dilihat pada gambar poster di bawah. Gambar 01. Hasil analisis dari aspek isi

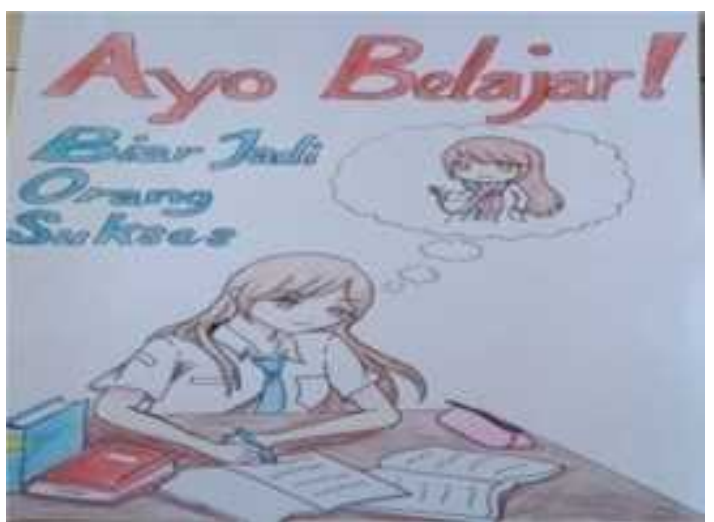

Poster di atas merupakan salah satu

\begin{tabular}{|c|c|c|c|c|}
\hline \multirow{2}{*}{\multicolumn{2}{|c|}{$\begin{array}{c}\text { Pokok Analisis } \\
\text { Nomor Data }\end{array}$}} & \multicolumn{3}{|c|}{ Deskripsi } \\
\hline & & & S3 & \\
\hline \multirow{2}{*}{\multicolumn{2}{|c|}{ Jenis Poster }} & \multicolumn{3}{|c|}{ Siaga } \\
\hline & & \multicolumn{3}{|c|}{$\begin{array}{l}\text { "Cornetto Kemasan } \\
\text { Baru dan Rasa yang } \\
\text { Sangat Lezat Sekali, } \\
\text { Ayo Beli Sebelum } \\
\text { Kehabisan" }\end{array}$} \\
\hline \multirow{4}{*}{$\begin{array}{l}\text { Analisis } \\
\text { dari Segi } \\
\text { Bahasa } \\
\text { (Keefekti } \\
\text { fan } \\
\text { Kalimat) }\end{array}$} & & Ya & Tdk. & $\begin{array}{l}\text { Keterang- } \\
\text { an }\end{array}$ \\
\hline & $\begin{array}{l}\text { Kesepa- } \\
\text { danan }\end{array}$ & $\checkmark$ & & \multirow{3}{*}{$\begin{array}{c}\text { Tdk } \\
\text { Lengkap }\end{array}$} \\
\hline & $\begin{array}{l}\text { Peneka- } \\
\text { nan }\end{array}$ & $\checkmark$ & & \\
\hline & $\begin{array}{l}\text { Kehe- } \\
\text { matan }\end{array}$ & & $\checkmark$ & \\
\hline
\end{tabular}

poster yang mengangkat tema tentang pendidikan. Poster tersebut berbunyi "Ayo Belajar! Biar jadi Orang Sukses". Jika dilihat, poster tersebut sudah menarik. Hal ini dapat dibuktikan dengan pemilihan warna yang bervariasi sehingga memperindah gambar yang ada pada poster tersebut. Selain menarik, komposisi gambar dan tulisan harus diperhatikan. Pada gambar 4.02 memiliki poin-poin utama dan tambahan, yang dipergunakan untuk membedakan kalimat. Poin utama pada poster siswa ini yakni "Ayo Belajar" sedangkan poin tambahan pada poster ini adalah "Biar Jadi Orang Sukses". Poin utama pada poster tersebut, bentuk tulisannya sengaja diperbesar karena pernyataan tersebut adalah inti dari poster yang dibuat. Sedangkan poin tambahan 
berfungsi untuk pelengkap agar, pernyataan tersebut mudah dipahami oleh khalayak. Bentuk tulisannya pun sudah baik ketika dibaca.

Kalimat yang digunakan sudah singkat dan padat. Pada poster yang dibuat oleh siswa dengan nomor data S14 antara kalimat dengan gambar sudah sesuai. Hal tersebut dapat dilihat pada gambar di atas, ada seorang anak yang sedang belajar. Namun, pada saat belajar ia tengah berkhayal jika suatu saat ia ingin menjadi guru. Untuk mengejar cita-citanya itu maka, ia harus belajar. Jadi aspek isi yang terdapat pada poster siswa dengan nomor data S14 dapat dikatakan baik.

Terdapat 9 (29,0\%) siswa yang menciptakan poster dikteriteria kurang menarik perhatian. 9 poster siswa tersebut dituliskan dengan nomor data S21, S27, S12, S11, S10, S02, S25, S30, dan S22. Hasil analisis dari salah datu poster siswa tersebut dapat dilihat pada gambar di bawah ini.

Gambar 02. Hasil analisis dari aspek isi

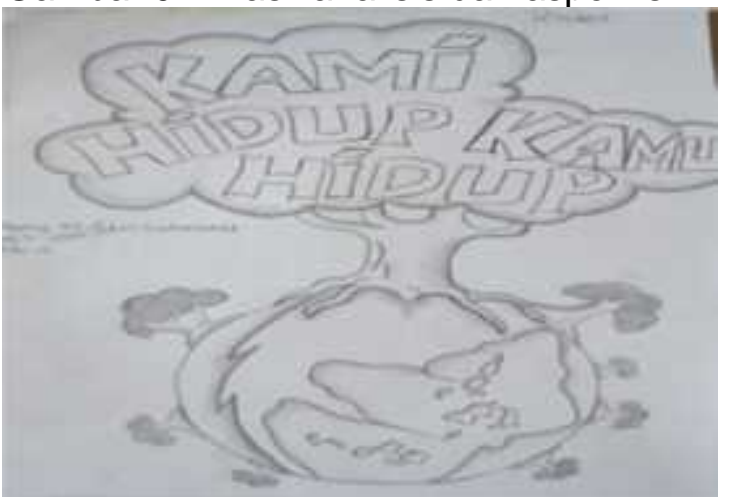

Poster di atas berbunyi "Kami Hidup Kamu Hidup" hasil kreativitas siswa dengan nomor data S21 mengangkat tema lingkungan hidup. Jika dilihat pada poster ini sudah menggunakan kalimat yang singkat dan padat. Namun, terdapat beberapa kekurangan atau kelemahan pada poster yang dibuat oleh siswa dengan nomor data S21 antara lain, komposisi warna yang masih kurang dan penempatan tulisan yang masih perlu diatur agar poster tersebut terlihat rapi dan menarik. Poster seharusnya lebih menekankan penggunaan warna-warna yang mencolok. Hal tersebut agar poster yang dibuat terlihat hidup ketika dipandang. Antara gambar dengan kalimat yang digunakan sudah saling berkaitan. Terlihat pada poster yang dibuat oleh nomor data S21 terdapat sebatang pohon yang sedang tumbuh di atas permukaan bumi. Pohon tersebut gambarnya sengaja lebih besar dibandingkan dengan gambar bumi yang ada di bawahnya. Hal tersebut karena, topik utama yang ingin disampaikan pada poster ini adalah tentang lingkungan hidup. Dengan demikian, betapa pentingnya kita sebagai makhluk hidup untuk saling menjaga satu sama lain. Jadi pada poster hasil kreativitas siswa dengan nomor data S21 masih perlu adanya penambahan warna dan penataan tulisan agar terlihat lebih baik ketika dilihat.

Terdapat $2(6,4 \%)$ yang membuat poster tidak sesui antara pernyaan dengan gambar yang digunakan. Dua siswa tersebut dinyatakan dengan nomor data $S$ 27 dan S 25. Hasil analisis dari salah satu poster siswa tersebut dapat dilihat pada gambar poster di bawah.

Gambar 03. Hasil analisis dari aspek isi

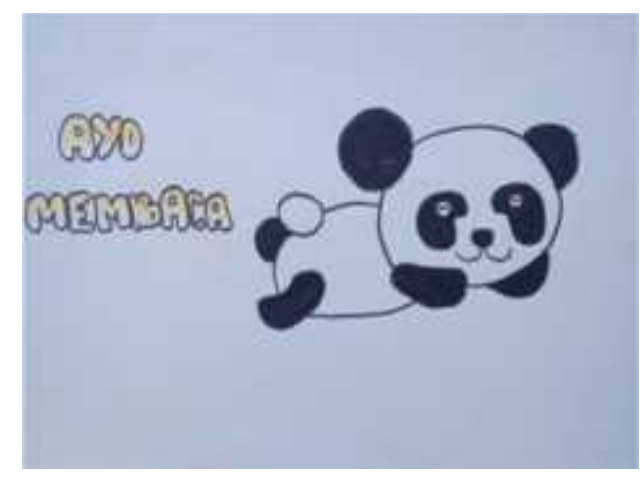

Poster hasil kreativitas siswa yang ditulis oleh nomor data S25 berbunyi "Ayo Membaca". Poster ini bertujuan untuk 
mengajak khayalak untuk selalu tekun dalam hal membaca. Jika dilihat dari kalimat yang digunakan sudah tergolong singkat dan persuasif. Poster ini merupakan salah satu poster yang bertemakan tentang pendidikan. Jika dilihat dari tampilan, poster ini sudah terlihat jelas dan mudah dibaca.Namun pada poster hasil karya siswa dengan nomor data S25 ini, dari unsur pewarnaannya masih kurang. Poster identik dengan penggunaan warna yang cerah dan mencolok. Hal tersebut bermaksud agar pembaca senantiasa melihat dan membaca isi poster. Pada poster di atas, memiliki poin utama yang merupakan titik fokus dari poster itu. Poin utama pada poster ini berbunyi "Ayo Membaca" karena tujuan dari poster ini yakni mengajak dan meyakinkan khalayak untuk selalu membaca. Jika dilihat dari keseluruhan isi poster antara gambar dengan pernyataan masih belum jelas. Hal tersebut dapat dibuktikan melalui gambar seekor panda yang sedang bersantai. Biasanya poster yang bergambar panda sangat identik dengan tempat wisata atau pun hiburan. Namun pada poster yang dibuat oleh nomor data S25 seekor panda dikaitkan dengan pembelajaran. Jadi hal tersebut kurang sesuai antara pemilihan gambar dengan kalimat yang digunakan.

\section{Pembahasan}

Keterampilan menulis poster adalah salah satu keterampilan yang harus dikuasai siswa SMP/MTs. Keterampilan menulis poster terdapat dalam Kurikulum Tingkat Satuan Pendidikan (KTSP) untuk siswa Sekolah Menengah Pertama (SMP) kelas VIII. Menulis slogan dan poster terdapat dalam Standar Kompetensi (SK): "Mengungkapkan informasi dalam bentuk rangkuman, teks berita, slogan/poster". Termuat dalam Kompetensi Dasar (KD): "Menulis slogan/poster untuk berbagai keperluan dengan pilihan kata dan kalimat yang bervariasi serta persuasif". Poster yang dibuat juga harus menarik perhatian pembaca karena tujuan dibuatnya poster adalah untuk memengaruhi atau mengajak pembaca. Keterampilan menulis siswa seringkali terhambat oleh sulitnya menemukan ide. Kesulitan menemukan ide ini salah satunya dipengaruhi oleh proses pembelajaran yang belum berhasil mendorong siswa untuk berpikir kreatif. Siswa diharapkan agar mampu memproduksi sebuah poster melalui pembelajaran ini.

Menulis poster merupakan proses kreatif yang berawal dari dorongan dalam diri untuk menciptaan sebuah karya. Kreativitas tersebut menyangkut tahapan pemikiran imajinatif, seperti: menghayati, merasakan, memikirkan, dan menemukan kegunaan poster tersebut.Poster pastilah mengandung beberapa pesan yang ingin disampaikan penulis kepada pembaca. Pesan yang disampaikan dalam bentuk kalimat tersebut haruslah bermanfaat serta memiliki daya pikat tinggi sehingga, pembaca dengan mudah akan mengingat hal yang ditonjolkan pada isi poster tersebut. Pengajaran poster tentunya akan berpengaruh besar terhadap cara pikir seseorang untuk mengembangkan kreativitas imajinatif siswa kemudian dituangkan ke dalam bentuk tulisan yang terdapat pada pembelajaran menulis poster.

Secara umum poster hasil kreativitas siswa kelas VIII A SMP Negeri 3 Singaraja sudah baik dan menarik. Diimbangi dengan bahasa yang singkat dan bervariatif sesui dengan kebutuhan di zaman sekarang. Siswa kelas VIII A SMP Negeri 3 Singaraja pada dasarnya sudah mampu menciptakan bahasa dengan menggunakan kalimat efektif jika dilihat dari kesepadanan kata, penekanan dan kehematan. Efektif dalam hal ini adalah ukuran kalimat yang mampu menjembatani 
timbulnya pikiran yang sama antara penulis dengan pembaca.

Dari hasil penelitian yang dipaparkan di atas, seluruh siswa kelas VIII A SMP Negeri 3 Singaraja secara umum sudah mampu menggunakan kalimat efektif dalam bahasa poster. Walaupun poster yang mereka buat lebih dominan mengambil tema pendidikan. Hal ini dikarenakan siswa lebih banyak menghabiskan waktu di sekolah dari pada di tempat lain. Seperti halnya poster yang dibuat oleh nomor data S17 dengan tema pendidikan. Poster ini menunjukkan bahwa adanya subjek dan predikat. Kata "bumi" berfungsi sebagai subjek, sedangkan kata "jagalah" berfungsi sebagai predikat.Poster ini sudah menggunakan kalimat efektif dalam bentuk kesepadanan adanya keterkaitan unsur satu dengan unsur lainnya. Jika dilihat dari penggunaan kalimat efektif dalam bentuk penekanan, poster hasil kreativitas siswa dengan nomor data S17 menunjukkan bahawa kata "jagalah" merupakan salah satu bentuk kata yang mengandung unsur penegasan. Hal ini ditandai dengan partikel penegas yaitu "lah" pada kata "jagalah". Kalimat dalam bentuk kehematan juga memiliki peran penting dalam poster.Pada poster yang ditulis oleh siswa dengan nomor data S17, sudah menggunakan kalimat yang singkat, padat dan berisi.

Dilihat dari aspek isi poster yang mencakup tiga subaspekdiantaranya: menarik perhatian, komposisi poster, dan kesesuaian antara gambar dengan kalimat. Poster yang ditulis oleh siswa kelas VIII A SMP Negeri 3 Singaraja sebagian besar sudah bagus. Pemilihan warna dalam isi poster sudah beranekaragam dan sesui dengan konteks. Poster yang dibuat hendaknya mempertimbangkan pembaca yang dituju. Selain menarik, komposisi poster juga berpengaruh terhadap isi poster. Komposisi tersebut berupa sebuah kalimat yang ditonjolkan dalam tampilan poster. Selain itu, poster sangat identik dengan gambar-gambar disertai dengan warna yang mencolok. Pemilihan gambar haruslah sesui dengan pernyataan yang diungkapkan pada poster tersebut.

Berdasarkan hasil penelitian yang telah dipaparkan, sebagian besar poster hasil kreativitas siswa sudah mudah dipahami dan jelas. Mudah dipahami ini dikarenakan bahasa yang digunakan tidak rumit dan menjelimet. Tampilan dan isi poster sudah terlihat menarik dengan diiringi gambar dan warna yang terlihat rapi dan mencolok. Poster yang ditulis oleh siswa ini juga memiliki komposisi yang berperan penting dalam isi poster. Komposisi inilah yang membedakan antara poin utama dengan poin tambahan. Pemilihan gambar pada poster haruslah sesui dengan kata-kata yang digunakan. Seperti halnya poster yang dibuat oleh nomor data S14 poster ini merupakan salah satu poster yang mengangkat tema tentang pendidikan. Poster tersebut berbunyi "Ayo Belajar! Biar jadi Orang Sukses". Jika dilihat, poster tersebut sudah menarik. Hal ini dapat dibuktikan dengan pemilihan warna yang bervariasi sehingga memperindah gambar yang ada pada poster tersebut. Selain menarik, komposisi gambar dan tulisan harus diperhatikan. Pada gambar 4.02 memiliki poin-poin utama dan tambahan, yang dipergunakan untuk membedakan kalimat. Poin utama pada poster siswa ini yakni "Ayo Belajar" sedangkan poin tambahan pada poster ini adalah "Biar Jadi Orang Sukses". Poin utama pada poster tersebut, bentuk tulisannya sengaja diperbesar karena pernyataan tersebut adalah inti dari poster yang dibuat sedangkan poin tambahan berfungsi untuk pelengkap agar pernyataan tersebut mudah dipahami oleh khalayak. Bentuk tulisannya pun sudah baik ketika dibaca. Kalimat yang digunakan sudah singkat dan padat. Pada poster yang dibuat oleh siswa dengan nomor data S14 antara kalimat dengan gambar sudah sesuai. Hal tersebut dapat dilihat pada gambar di atas, 
ada seorang anak yang sedang belajar. Namun, pada saat belajar ia tengah berkhayal jika suatu saat ia ingin menjadi guru. Untuk mengejar cita-citanya itu maka, ia harus belajar. Aspek isi yang terdapat pada poster siswa dengan nomor data S14 dapat dikatakan baik.Jadi dari 31 poster yang sudah penulis analisis terdapat 23 $(74,1 \%)$ orang yang berhasil menulis poster dengan kriteria menarik, terdapat 24 $(77,4 \%)$ siswa yang berhasil dalam menulis komposisi poster, dan 29 (93,5\%) poster siswa yang sudah sesuai antara pernyataan dengan isi poster.

\section{PENUTUP}

Berdasarkan hasil penelitian dan pembahasan bab IV dapat disimpulkan (1) analisis poster hasil kreativitas siswa kelas VIII A SMP Negeri 3 Singaraja, yaitu seluruh siswa kelas VIII A sudah mampu menciptakan poster menggunakan bahasa dengan kalimat efektif yang baik. Dari 31 (100\%) poster yang ada, $23(74,1)$ siswa yang berhasil menggunakan kalimat efektif dalam bentuk kesepadanan, sebanyak 27 (87\%) siswa yang berhasil menggunakan kalimat efektif dalam bentuk penekanan dan $20 \quad(64,5 \%)$ siswa yang berhasil menggunakan kalimat efektif dalam bentuk kehematan. (2) Dilihat dari aspek isi, adanya tiga subaspek yang ada pada isi poster diantaranya: menarik perhatian, komposisi poster dan kesesuaian antara gambar dengan pernyatan. Poster hasil kreativitas siswa kelas VIII A SMP Negeri 3 Singaraja sebagain besar sudah menunjukkan adanya tiga subaspek tersebut. Poster yang mereka buat sebagian besar mengambil tema tentang pendidikan. Siswa membuat poster sesuai dengan apa yang mereka alami, lihat, atau pun dengar. Dari hasil analisis yang dilakukan, $31(100 \%)$ poster siswa terdapat $23(74,1 \%)$ yang berhasil menulis poster dikriteria menarik, terdapat $24 \quad(77,4 \%)$ komposisi poster, dan 29 (93,5\%) poster yang sudah sesuai antara gambar dengan pernyataan.

Berdasarkan pemaparan mengenai hasil penelitian dan simpulan, terdapat dua saran yang dapat disampaikan dalam penelitian ini. Pertama, siswa diharapkan mampu mempertahankan hasil belajar mengenai menulis poster baik dari aspek bahasa maupun isi. Teruslah berlatih menulis poster sehingga apa yang ingin disampaikan penulis terhadap khalayak dapat dipahami dengan baik. Kedua, bagi peneliti lain yang akan mengadakan penelitian, hasil jangkauan penelitian ini dapat diperluas. Peneliti lain dapat melakukan penelitian berupa analisis pola sintaksis pada poster hasil kreativitas siswa dan makna secara semantik yang terkandung dalam isi poster.

\section{DAFTAR RUJUKAN}

Arikunto, Suharsini. 2006. Manajemen Penelitian. Jakarta: PT Rineka Cipta.

Balitbang. 2002. Kurikulum Berbasis Kompetensi: Kurikulum dan Hasil Belajar (KHB). Jakarta: Bumi Aksara.

Sadiman, Arief S. dkk. 2007. Media Pendidikan: Pengertian,

Pengembangan, dan Pemanfaatannya. Jakarta: PT Raja Grafindo Persada.

Slamet, St.Y. \& Khundharu Sadhono. 2009. Pembelajaran Keterampilan Berbahasa Indonesia: Teori dan Aplikasi. Karanganyar: Cakra Books.

Sudjana, dkk. 2007. Media Pengajaran. Bandung: Sinar Baru Algensid.

Suryana. 2010. MetodePengantarPenelitian Model Praktis Kuantitatif dan Kualitatif Buku Ajar Perkuliahan. Bandung: Universitas Pendidikan Indonesia. 